症例報告

\author{
超高齢者気胸の 1 手術例 \\ 竹下 伸二1,2) 村松高2) 田中 洋子2) 富塚 龍也 ${ }^{1)}$ \\ 小室 万里 ${ }^{1)}$ 根岸 七雄 ${ }^{1)}$ 塩野 元美2) \\ 1)武蔵野総合病院外科 \\ 2) 日本大学医学部心臓血管 · 呼吸器 · 総合外科学分野
}

\title{
Thoracoscopic Surgery for Refractory Pneumothorax in a Senior Citizen
}

Shinji Takeshita ${ }^{1,2)}$, Takashi Muramatsu ${ }^{2)}$, Yoko TnanakA ${ }^{2)}$, Tatsuya Tomizuka ${ }^{1)}$, Masato KomUro ${ }^{1)}$, Nanao NeGISHI ${ }^{1)}$ and Motomi SHIONO ${ }^{2)}$

${ }^{1)}$ Department of Surgery, Musashino General Hospital

${ }^{2}$ Department of Cardiovasucular, Respiratory, General Surgery, Nihon University School of Medicine

A 93-year-old man was admitted to our hospital due to dyspnea and cough caused by right spontaneous pneumothorax. Chest CT showed right lung collapse and bullas in the right upper, middle, and lower lobes. A chest tube thoracotomy was placed immediately. Nevertheless, chest drainage did not improve the pneumothorax, and the air leak persisted for 2 weeks. We conducted thoracographic studies and bubbles showed from a bulla in the upper lobe. Considering his age, condition, respiratory function, and performance status, we carried out ligation of the bulla on the upper lobe by videoassisted thoracic surgery under local and epidural anesthesia. The postoperative course was good and the patient was discharged from the hospital after the third postoperative day.

Key words: senior citizen, refractory peumothorax, thoracographic study, epidural anesthesia 超高齢者, 難治性気胸, 胸腔造影, 硬膜外麻酔

(J. Nihon Univ. Med. Ass., 2010; 69 (5): 313-316)

要旨 症例は93歳, 男性 . 主訴は呼吸苦. 右自然気胸 に対し保存的治療後に早期再発および遷延する気漏を認 めたため手術を考慮した。術前に施行した胸腔造影にお いて右肺尖部からの気漏を確認した・超高齢者でかつ低 肺機能が予測されたため，硬膜外麻酔，局所麻酔下に手 術を施行した。手術は 2 ポートで内視鏡用結紮系を用い て, 肺尖部の囊胞の根部を 2 重結紮, さらに PGA シー 卜を貼付した。術後経過良好で術後第 3 病日に退院とな った。

\section{はじめに}

再発気胸の治療は, 根治性の高さから一般的には全身 麻酔下による胸腔鏡下手術が最も多く行われている．し かし, 生体への過度の侵襲を及ぼす全身麻酔下の手術 は, 藏器予備能の低い高齢者や全身状態不良患者では困 難な場合が少なくない．このようなハイリスク患者では 胸膜癒着などの保存的治療法を選択することが多いが, 適切な結果が得られていない状況である.今回, 胸腔造 影検查にて気胸の原因となる囊胞を確定後に, 硬膜外麻 酔および局所麻酔下に胸腔鏡下手術を施行し，良好な結 果を得た 1 例を経験したので若干の文献的考察を加え報 告する．

\section{I. 症例}

症 例: 93 歳 男性.

主 訴: 呼吸苦およひ咳嗽。

既往歴 : 高血圧症, アルツハイマー型認知症, 腹部大 動脈瘤, 呼吸器系疾患の指摘なし。喫煙 : 過去 20 本/日/ 60 年以上, 現在禁煙 : 10 年間 .

現病歴: 平成 21 年 9 月上旬頃から咳嗽が出現, 呼吸 苦も自覚するようになったため近医を受診. 产の際の胸 部単純 X線写真上, 中等度の右肺虚脱を認奴, 右自然気 胸の診断下, 当院紹介となった。当院初診時の胸部単純 X線写真上，中等度虚脱の右自然気胸を認めた (Fig. 1) . 胸部 CT では, 右肺尖部, 中葉, 下葉外側に気腫性変化 を認めた。また，健側である左肺にも気腫化と間質性変 化を認めた (Fig. 2) .

入院時所見 : $\mathrm{SpO}_{2}$ 87 92\% (room air), 血圧 158/77 $\mathrm{mmHg}$. 血液検査では白血球 $12600 / \mu l, C R P 7.41 \mathrm{mg} / \mathrm{d} l$ と炎症反応の上昇を認めた . 血液ガス分析は room air に おいて $\mathrm{PaO}_{2} 69 \mathrm{mmHg}, \mathrm{PaCO}_{2} 45 \mathrm{mmHg}$ であった .

入院後経過 : 入院後, 直ちに胸腔ドレナージ施行. 肺 の伸展良好で, 気漏なく経過し, 第 4 病日にミノサイク リン塩酸塩 $100 \mathrm{mg}$ を胸膜癒着目的に胸腔内へ投与し, ドレーンを抜去した . しかし, 胸腔ドレーン抜去 2 日目

本論文の要旨は, 第 495 回日本大学医学会例会 (2010 年 1 月) において発表されたものである .

受付: 2010 年 7 月 26 日, 受理 : 2010 年 8 月 17 日 


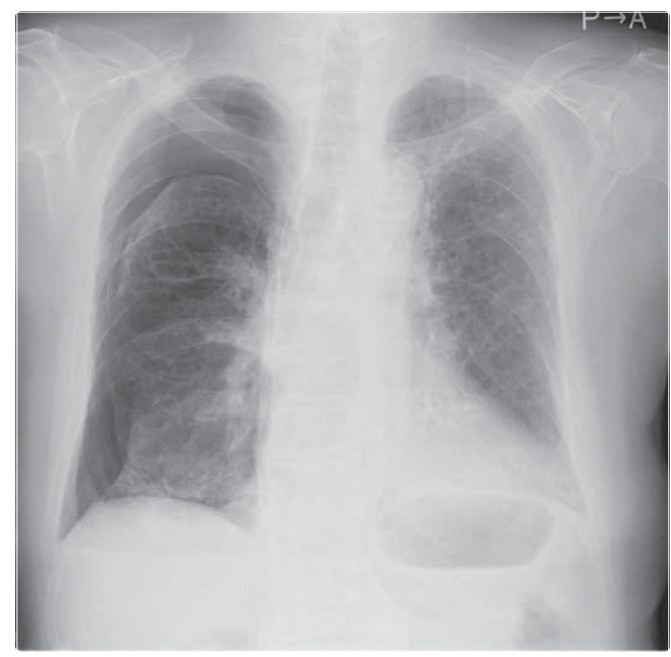

Fig. 1 Chest radiograph showed right spontaneous pneumothorax.

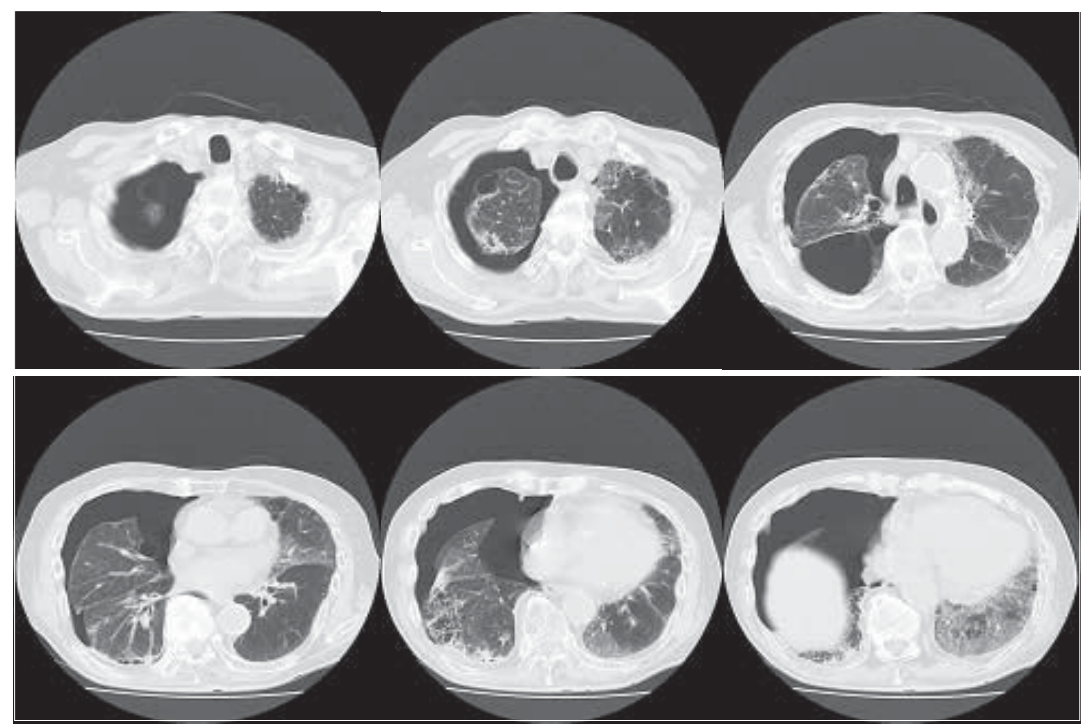

Fig. 2 Computed assisted tomography showed right spontaneous peumothorax and bullas of right upper lobe, middle lobe, lower lobe.

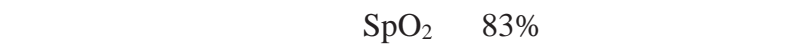
$\mathrm{X}$ 線写真上, 再度中等度虚脱の右自然気胸を認めた。前 回胸腔内に投与したミノサイクリン塩酸塩による癒着は 全く認められなかった . 再度胸腔ドレナージ施行し, 持 続吸引で経過観察した . 肺の伸展良好であったが, 2 週 間以上気漏が遷延した .93 歳であり, ADL (Activities of Daily Living) は Performance Status (以下 PS) 2 ,低肺機 能，健側肺の状態も全身麻酔による片肺換気に対するリ スクが高いと判断された．しかし，気漏が遷延したため 手術を念頭に胸腔造影を施行した。胸部 CT 所見から右 肺尖部の囊胞が責任病変と推測し, 胸腔ドレーンから造 影剂を注入して胸腔造影を施行したところ, 右肺尖部に 径 $3 \mathrm{~cm}$ の囊胞からの気漏を確認した (Fig. 3). 弚の後も 気漏の減少を認めなかったため, 本人, 家族へ十分に病 状や手術での効果と不利益について説明した上で手術を 行うこととなった .
術前血液検査上，WBC 7600/ $\mu l ， \mathrm{CRP} 1.64 \mathrm{mg} / \mathrm{d} l$ と若 干の炎症反応の上昇と, $\mathrm{Hb} 10.5 \mathrm{~g} / \mathrm{d} l$ と軽度の貧血を認 めたが，光の他は年齢を考慮すると問題ないと判断され た。気漏が持続する気胸であるため術前の呼吸機能検査 は施行できなかったが, 血液ガス分析上, I 型呼吸不全 を認め，また気腫化と線維化を呈する胸部単純 X線写真 所見から低肺機能が予測された . 一方心エコー上, EF $61 \%$ で心機能は問題ないと判断された . 超高齢者, 低肺 機能, 全身麻酔, 分離肺換気のリスクを考慮し, 硬膜外 麻酔，局所麻酔下に手術を施行する方針となった。

手術所見：硬膜外麻酔，局所麻酔下，左側臥位に固定 し, 手術施行. $5 \mathrm{~mm}$ の 2 ポートを胸腔内に挿入し, 5 $\mathrm{mm}$ の光学視管と内視鏡用ツッペルを用いて胸腔鏡を用 いて胸腔内を観察した . 肺尖部を観察したところ壁か薄 く白色に混濁した囊胞を認めた . 胸腔ドレーンの位置と 術前に施行した胸腔造影所見より，この囊胞が責任病変 


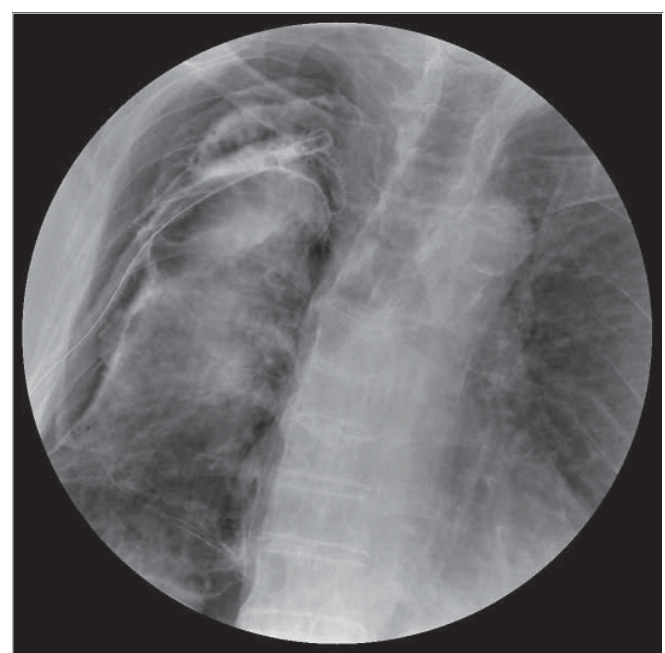

Fig. 3 Thoracographic studies showed bubbles from a bulla of upper lobe.

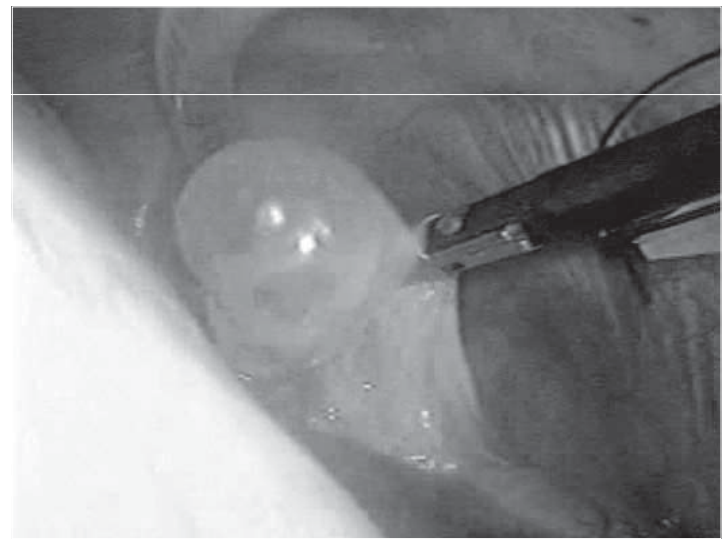

Fig. 4 Operative findings; we found pulmonary bulla at the top of upper lobe through thoracoscopy.

と判断し，内視鏡用結紮系 (エンドループ®) を用いてこ の囊胞の根部を 2 重結紮した .さらにPGA シート(ネ オベールシート®)を貼付し, ドレーンを留置, 手術時間 20 分で閉創 . 持続吸引を開始したところ気漏を全く認め なかった (Fig. 4) . 術後 , 帰室後より飲水可能 , 離床可能 な状態であった . 術後経過良好であり，術後第 1 病日に ドレーンをクランプ．術後第 2 病日，ドレーンを抜去． 術後第 3 病日に退院となった . 現在外来に定期的に経過 観察しているが, 術後10 ケ月の現在 , 再発の兆候は認め ていない .

\section{II. 考 察}

近年，高齢者の自然気胸が増加しており，光の多く は，重喫煙者の気腫肺による難治性気胸である．さらに これらの症例では, 基礎疾患, 低肺機能, ADL 不良など の理由により全身麻酔が困難なことが多く，全身麻酔後 の抜管困難状態や，ドレーン長期留置により，肺炎，膿
胸に陥り，死亡する症例も少なくからず存在している． 後藤ら ${ }^{1)}$ ( 80 歳以上の術前平均ドレナージ期間は 29 日 で，長期となっていると報告している．乥こで，高龄者 の気漏遷延症例に対しては, 各施設において, ミノサイ クリン塩酸塩，OK-432,自己血などの胸腔内投与によ る癒着療法や，造影剂希䣋フィブリン糊大量胸腔内投 与2)など樣々な創意工夫がなされている状態である．し かし, 肺の十分な伸展が得られていなければ，有効な癒 着は期待できず，光の治療効果の確実性にもかける33). 本症例においても初回発症時にミノサイクリン塩酸塩を 胸腔内へ投与したが, 肺の伸展が十分にも関わらず, 癒 着効果は得られなかった . また，再発の際には OK-432 投与を考慮したが, 肺の伸展不良であったため, 投与し なかった .さらに，難治性気胸に対する兴の他の保存的 治療法として，気管支鏡による気管支充填術も少数の施

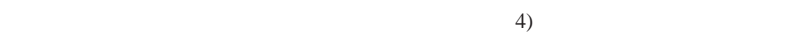
充填術単独による治療効果より胸膜癒着との併用によっ て有効な゙治療効果が得られ，難治性気胸に対し有用であ るとし，渡辺ら ${ }^{5)}$ はシリコン性気管支充填剂を用いた気 管支充填術は難治性気胸に有効であると報告している。 本症例に対しても気管支充填術を考慮したが，低肺機能 であり健側肺の間質陰影も認められていたため気管支鏡 下の処置はリスクが高く，確実性にかけると判断した . 谷村ら ${ }^{6}$ (は気漏が遷延する高齢者気胸に対して全身状態 が不良になる前に手術適応を決定し対処すべきであると 報告しているが，未だに超高齢者の難治性気胸に対し， 外科的治療の安全かつ有効な治療法は確立されていない のか現状である．野田ら ${ }^{7}$ (は高齢者難治性気胸では術前 のPS 不良，酸素投与群に対する全身麻酔による手術は 術後合併症リスクが高く，手術適応には慎重かつ十分な 検討が必要であり，十分なインフォームドコンセントが 必要としている．本症例では，心機能，血液学的検査所 見は容認できる範囲内であったが, 年齢, 術前 PS 2 , 術 前酸素投与が必要な状態であり，全身麻酔による手術は 合併症のリスクが高いと判断した . 弚こで, 術前検査と して胸部 CT 所見を基に胸腔造影を適切に行い, 気漏部 位，責任病巣の推定を行い，手術時間の短縮や合併症リ スクの軽減を計る事が出来たと思われる．今後，本症例 と同樣に高齢者の難治性気胸に対しては積極的に胸腔造 影を行い, 気漏部位, 責任病巣の推定後には漫然とした 保存的治療の継続ではなく，低侵襲である硬膜外麻酔， 局所麻酔での手術を検討するべきである，光の際には， 本人, 家族への十分なインフォームドコンセントが必要 であり，基礎疾患のコントロール，感染コントロールが 必要であり，またPS 2 までは手術が考慮できると考える。

$$
\text { ま と め }
$$

93 歳の超高齢者の，低肺機能の難治性気胸に対して， 硬膜外麻整，局所麻酔下に胸腔鏡下手術を施行し，良好 
な結果を得た 1 例を経験したので報告した．今後も同樣 な症例に対しては, 無意味に保存的加療せずに気漏部位 か確認出来た場合, 硬膜外麻酔, 局所麻酔の手術を施行 するべきであると考える．

\section{文献}

1) 後藤正司, 古川幸穂, 元石 充, 他 . 超高齢者気胸 (80 歳 以上) の検討. 気胸，2002; 5: 61-62.

2) 木下貴裕，鈴間孝臣，重里政信，他 . 胸部手術後難治性 肺瘻に対する造影剂希勫フィブリン糊の大量胸腔内注入 療法の臨床的研究 不成功例 2 例を含む 25 例の検討 . 日 本呼吸器外科学会䧱誌, 2004; 18: 527-531.

3) 阪口全宏, 中村憲二, 高橋 修, 他 . 繰り返し気胸を発 症した肺リンパ管脈管筋腫症の 1 例一肺移植対象疾患で
の胸膜癒着術に関する考察一。日本呼吸器外科学会雑 誌, 2006; 20: 781-785.

4) 本間崇浩，新納英樹，宮澤秀樹，他 . 難治性気胸に対す る治療戦略一気管支充填術と $50 \mathrm{cmH}_{2} \mathrm{O}$ 陰圧下に行う胸 膜癒着療法の併用一。 日本呼吸器外科学会雑誌, 2009; 23: $114-119$.

5) 渡辺洋一, 松尾圭祐, 玉置明彦, 他. 難治性気胸, 気管 支瘻に対する EWS (Endobronchial Watanabe Spigot)，気管 支学，2001; 23: 510-515.

6) 谷村繁雄, 生井世雄, 横場正典, 他. 呼吸器外科の参入 が地域の高齢者気胸の治療にもたらした効果 . 日本気 胸・襄胞性肺疾患学会杂隹誌, 2004; 6: 40-43.

7) 野田雅史, 佐渡 哲, 桜田晃, 他 . 高齢者難治性気胸 の術後合併症リスク評価. 日本呼吸器外科学会杂倠志, 2008; 22: 856-859. 